\title{
Intercultural communication in solving a current global problem: the COVID pandemic
}

ISSN 2657-9774; https://doi.org/10.36534/erlj.2021.01.06

Eva Pechočiaková Svitačová

Faculty of Economics and Management, Slovak University of

Agriculture in Nitra, Slovakia; eva.svitacova@uniag.sk

\begin{abstract}
Intercultural communication is a type of social interaction in a multicultural society, which can help to solve problems related to the coexistence of cultures, as well as global problems that affect all people on Earth, regardless of cultural affiliation. Currently, such a problem is the COVID pandemic. In an effort to find solutions that respect the rights and interests of members of all cultures, this paper first introduces the policy of multiculturalism, but it focuses mainly on the importance of intercultural communication in the multicultural society which, among other things, helps the members to realize that fighting against this pandemic and dealing with its consequences is a common good for all of them. They should work together for this good to respect the interests of all people and cultures in the world. At the same time, the COVID pandemic becomes a challenge for ethics to strengthen the cohesion and cooperation of cultures and, from its point of view, to predict a solution for the benefit of everyone.
\end{abstract}

Keywords: COVID pandemic, cultures, multiculturalism, intercultural communication, common good, ethics

\section{Introduction}

In today's multicultural world, globalization processes enable rapid communication between distant countries and continents and, among other things, help people from various cultural, religious or ethnic groups and communities to communicate on solving various issues. Also, with regard to the global problems that accompany phenomena of globalization, the undesirable consequences of these problems more or less affect all inhabitants of the Earth, regardless of culture to which they belong. Their solution should be based on mutual agreements on the values that unite people as participants of different cultures, as well as on the recognition of different values and peculiarities of individual cultures. Also, in respect of this, the attention is paid to the policy of multiculturalism and to intercultural communication. Thanks to this, mutual understanding can be achieved between members of different cultures, which in turn can allow the establishment of satisfactory social order in society and the implementation of cooperation in solving multiple problems, not only those related to their coexistence, but also such urgent issues as the COVID pandemic, which is a common threat to the whole world.

\section{Theoretical background}

\section{Multiculturalism and the problem of cultural recognition}

The concept of coexistence of people belonging to different cultures and religions in one territory within the legally consistent state, is most often referred to as multiculturalism. It is an approach that refers to culture, respectively to the variety of cultures and relies on the basis of pluralism, on the legitimization of the peculiarities of individual cultures ${ }^{1}$, as well as on their members (Jakoubek

\footnotetext{
${ }^{1}$ The semantic field of the term culture derives from the Latin colere / cultio - machining, processing. Originally, the Latin "colere" connoted a higher quality attribute. It was associated with processes aimed at improving the natural (naturally existing) environment. "Colere" connotes the process and the result of the cultivation process; primarily agricultural crops and livestock. Later, it corresponded to the idea of the mission of human as a rational being capable of developing various
} 
2005). Today's multicultural society is the result of globalization processes. It is the so-called multiculturalism of the global era, i.e. global age, while in democratic society two forms of multiculturalism are most often distinguished: liberal and communitarian. ${ }^{2}$

We often encounter the sign that multiculturalism is a concept of coexistence, but it needs to be noted that it is not always about peaceful "coexistence," but rather coexistence of members and groups in the multicultural society. Manifestations of intolerance, conflicts and commotions cannot be overlooked. We do not consider the definition of multiculturalism as the concept of coexistence as fully correct, even from the point of semantics view. The linguistic meaning of the word "coexistence" refers to the circumstantial modification of the story, while the above-mentioned characteristic of multiculturalism from a qualitative point of view evokes the idea of peaceful coexistence of cultures and their members in the multicultural society, which may not be applied to every multicultural society. Due to the many societal changes that accompany globalization, cultural diversity has been deepening in societies, and incidents in several countries confirm that it is not always about the peaceful coexistence of members of various cultures.

On the other hand, multiculturalism requires the recognition and protection of the cultural and racial diversity of society as a fundamental feature of its identity. We find the requirement of recognition of the equal value of different cultures in contemporary communitarianism, and as some of its representatives ${ }^{3}$ emphasize, the coexistence of different cultural units does not mean the loss of the authenticity of the given cultures. Multiculturalism advocates that individual cultures shall complement and intertwine together, not separate from each other. Public policy in the multicultural society also focuses on managing cultural diversity, ensuring mutual respect and recognizing cultural differences within a country. In particular, multiculturalism tries to provide the peaceful coexistence of cultures, while it is important that it will be based on solidary relations.

The policy of multiculturalism should be used to support the socialization of different groups of citizens. It requires the openness of one culture to another, and the assurance of a constructive dialogue which results in the discovery of common and different elements in various cultures. As Taylor stated, "all human cultures, which have filled the lives of society for a long time, are able to say something important to all people" (Taylor 2001: 83). He stresses the need to accept the equal value of different cultures, while noting that we should not only let them live, but we should also accept their value, because he believes that if one group in the multicultural society does not accept the value of another one, it can lead to the disintegration of such society.

Honneth (1997) deals with the problem of recognition in communitarianism. He not only demands legal recognition of the citizens of society, which shall ensure their protection against personal identity violations, but also considers the recognition of difference. This is based on solidarity, thanks to which individuals gain self-esteem in a "morally integrated community" with regard to commonly shared values. In his theory, Honneth pays attention to the mutual recognition of individuals in communities, which takes place in terms of how they can preserve and enhance common values there. He points out that the mutual respect and esteem of the members of community stems more from cultural self-understanding based on common values and common convictions than from the public recognition of the rights and freedoms of others (Cf. Hooneth 1997). ${ }^{4}$

forms of the world; but also to improve oneself. Processing, improvement, cultivation in many European languages therefore develops and specifies the "impact" of the basic process of "cultio" (Slušná 2005).

2 The genesis of forms of multiculturalism can be observed in the dispute between liberalism and communitarianism. One area where the dispute between liberalism and communitarianism still finds a breeding ground is multiculturalism (see more: Velek 1996). Socio-philosophical stream - communitarianism does not have a unified conception of its learning. It is often referred to as a communitarian critique of liberal theory. Its representatives reject the idea of society in which individuals are interested in creating a favourable cultural environment, can respect each other and can be recognized as dignified beings as well as unique individuals, while being able to participate together in a common culture.

${ }^{3}$ See, for example, Taylor (2001), or Walzer (2002).

${ }^{4} \mathrm{~A}$. Adler believed that the basic need of every person is to belong to the human community and to feel that he has a place in it (see more in, Marková and Mandzáková 2014). 
Taylor combines the demand for recognition with the policy of multiculturalism and reflects both on a policy of equal dignity and on a policy of difference. The policy of equal dignity is based on the identical set of rights and freedoms, on the basis of which respect, esteem and recognition belong to each citizen, and on the policy of difference, according to which the peculiarity of individuals or groups, their unique identity, shall be respected and recognized. He thinks that: "Just as all people, regardless of race or culture, must have equal civil rights and equal voting rights, everyone should enjoy from the assumption that their traditional culture has value" (Taylor 2001: 85). According to Taylor, the policy of equal dignity places a sign of equality between the identities of all individuals, so that what the public policy recognizes through equal rights is not the uniqueness of the identities of individuals. It reduces the unique individuals and uniqueness of their lives, goals, to the abstract identity of equality. Therefore, he seeks to complement the equal dignity with the policy of difference, where emphasizing the recognition that is not focused on the abstractly equal identities of human, but on the recognition of unique, authentic identities not only of individuals, and also on the recognition of cultural communities. Taylor advocates a policy of differentiated recognition, which should to some extent respect, albeit not a unique identity, but at least a special identity of certain communities. According to Taylor, such society, which is "blind" 5 to the differences, can be marked not only as inhuman but also as highly discriminatory, and thus he demands to apply the policy of difference especially in society in which minority cultures exist. Along with these types of policies, he also outlines an ethics of multiculturalism, when requiring from the members of the multicultural society to respect established legal requirements as well as differences, and to prevent discrimination, which stems from the requirement of humanism. Such socialized members are able to communicate with each other about solving various problems. It is the intercultural communication, thanks to which they are able to participate together in solving many problems.

\section{Intercultural communication as a prerequisite for solving problems in current world}

We are of the opinion that: "We have many ways to communicate with each other. Sometimes it is not a question of whether we understand each other or know each other, whether we tolerate each other or not, but whether we can live together, acknowledge our perspectives and respect each other. According to this, we finally formulate our mutual dialogue, both at the level of cultures and rights, and between each other" (Solík 2010). Engaging in dialogue, which is the most typical representative of communication, is much more urgent but also more demanding in the community that consists of members of more cultures.

"The starting point for the study of intercultural communication should be mainly three related concepts: communication, culture and interculturality" (Moravčíková 2020: 94). Communication (from Latin communicare) can be defined as doing something in a common way, consulting, negotiating, communicating, announcing or exchanging information. The information that is transmitted by communication ceases to be only a private matter and becomes common, social (for more details see: Watzlawick, Bavelasová \& Jackson 1999, Janoušek 1984). In general, communication is classified also as conjunctive interaction, it is treated as a basic tool for forming interpersonal relationships, but it also has other functions. Through this interaction, people socialize in groups, communities and societies. "Human is integrated into the community mainly through comprehensive interpersonal communication and individual communication of acts" (Lomnický et al. 2019: 53).

For example, Krech, Crutchfield and Ballachey (1968) characterize communication as the exchange of meanings between people. Nakonečný (2009) characterizes it as a kind of social interaction in which it is a unilateral transfer or exchange of information. Mikulaštík (2010) understands communication as an exchange of meanings between people, using a common system

\footnotetext{
${ }^{5}$ This is the so-called "cultural blindness". According to W. Kymlicka (1995), the approach is based on the effort not to discriminate and to ensure equal conditions for all without distinction.

6 Social communication, i.e. the communication among people becomes a specific type of communication. This process deals with mutual understanding of people, exchange of opinions, attitudes, information of inner perception of a certain situation to participants of communication.
} 
of symbols. From the above mentioned and also from other definitions of communication, it is clear that communication is a social interaction in which there is the transmission of certain content with a certain meaning. Through communication social structures are interconnected; social management and other ties in society are formed.

Communication has two main aspects: contentual (denotative) and relational (connotative), while the contentual level is the carrier of information and the relational level determines how the information should be understood (Mikulaštík 2010). It is implemented through language, as a system of special character values / signals and symbols / and the rules for their connection. In this way, the meaning is transferred between people, based on the coding of the information by the communicator and the decoding of the information by the communicant which, however, requires the communicator to understand the given language in which the information was encoded. The basis of any successful communication is therefore the effective transmission of information through language and its correct understanding by the recipient. Except for the verbal communication dealing with the questions of effective use of language devices within the process of comprehension there is nonverbal communication. It is an essential complement of the verbal communication as it leans on the use of nonverbal signals (miming, gestures, proxemics, etc. At the same time, in order for the recipient to understand the given information correctly, it is not enough to have the same language in which the information is encoded and decoded. Mutual communication between the participants in communication (agents and percipient, or communicator and communicant) also depends on their value systems. Also for this reason, intercultural communication can be a much more demanding type of communication than the communication in a society composed of members of one common culture, intercultural communication is the type of communication that transcends the borders of the home State.

Intercultural communication ${ }^{7}$ is one of the relatively young fields of study in the world. The beginnings of its formal research date back to the 1940s, when it was a part of the linguistic and cultural training of American diplomats. Hall also drew from this environment of nonverbal signal use in his book "The Silent Language" (1959), which became the starting point for many other works in the field of intercultural communication. Gradually, experts began to deal more thoroughly with the study of communication in the context of culture, and at the same time the study of cultures in terms of the laws of communication. Intercultural communication is interdisciplinary, based on intercultural psychology, and many other disciplines are involved in its research. ${ }^{8}$ Methodologically, it approaches the overcoming of cultural differences. It is determined by the specifics of languages, cultures, mentalities and value systems of communicating partners. Its aim is to achieve mutual understanding between members of cultures in the private sphere, in public, and as pointed above, understanding in the multicultural society about rights and freedoms is considered particularly important. Based on them, the members of such societies develop policy which allows them free realization.

"Mutual pre-understanding - the assumption that people understand each other in a short period of time of their life story, it means, they will interconnect personal transgenerational experience ${ }^{9}-$ is related not only to the educational, but also to the socialization and enculturation process. Today's society is no longer limited by the borders of one State, or the continent, and we do not even talk about the virtual world" (Vadíková 2015: 50). Individuals from different cultural contexts enter into

\footnotetext{
7 Intercultural communication is also a scientific discipline that examines the connections between language and culture, interactions between people and / or groups with different cultural backgrounds, and thus the perception and understanding of the world in different ethnic, racial or religious communities. Its aim is to streamline communication between individuals or groups, increase intercultural awareness. It emphasizes perception in a dual perspective, by which it methodically approaches the overcoming of cultural differences (Moravčíková 2020).

8 In linguistics, rather a narrower definition of intercultural communication is treated: "When we are dealing with the interpersonal communication situation between participants of different cultural groups, we can mark this interaction as the intercultural communication" (Litters 1995).

${ }^{9}$ Regarding the term transgeneration we suppose the life story of a particular person reflecting the message of the previous generations and living their own life stories as an input for current but also future generations (Cf. Vadíková 2015).
} 
communication situations, interact, and their mental schemas are influenced by different ways of thinking, patterns of behavior, patterns of perception, different value orientations, etc. (Mikulášová \& Mikuláš 2014). It brings many positive benefits, such as getting to know foreign cultures, cultural enrichment, education, democratization, cooperation, and also raising intercultural awareness. This allows us to understand ourselves by confronting our diversity. But this understanding first requires a dialogue in which "we all shall recognize the equal value of different cultures" (Taylor 2001: 80). At the same time, it is worth noting that intercultural communication can also bring negative phenomena - such as misunderstandings that can lead to military or terrorist attacks, or other kinds of conflicts.

Intercultural communication is based on pluralism, which refers to the state of existence of diverse worldview aspects interpreted on spiritual, cultural, as well as value levels. According to $G$. Sartori, such pluralism evokes the need for a discussion with diversity, through which we reach not only a true awareness of ourselves, but also an understanding of it. This pluralism, according to Sartori (2005), brings the discussion with the difference through which we get to true realization of us but also to the understanding. "From the point of view of pluralism, diversity and dissenting views are among the values that enrich the individual and his political community" (Sartori 2005: 16).

Similarly, J. S. Mill (1995) considers cultural diversity to be the source and basis of the wealth of the whole community. Although in his famous essay he primarily tried to defend the freedom of the human individual in society, he also indirectly defended the plurality of opinions, beliefs, or ways of life, while emphasizing that they require tolerance. He was thinking about the question as to what European nations actually do to belong to a perfective and not to a stagnant humanity. The answer is that although individuals, groups, and nations differ from each other and have taken different paths, each of these paths had led to something valuable. According to him, Europe as we know it exists due to its progress and versatility built from the plurality of paths. Mill notes that in each era, there were those who were intolerant to each other, but their efforts to confound the development of others had very rarely a lasting success. Also by this, he tried to indicate that the development and progress are possible thanks to the confrontation of diverse views and beliefs of members of cultures and mutual tolerance (Mill 1995). On behalf of dignified coexistence and mainly cooperation, mutual understanding is required in many areas of life, despite many differences. At the same time, according to him, this understanding leads to the solution of problems that concern the multicultural society. As we still have a lot of unsolved problems in multicultural society and a lot more appear, it means that mutual understanding of cultures and finding solutions means a difficult task that is essential in every period and historical time. We can achieve it on the basis of dialogue, which is at the same time intercultural, and which is based on the acceptance of the plurality of worldviews, customs, traditions or rituals in the communication of other cultures but also forms and expressions of culturally different but equal languages.

This is obviously evident also for the European Parliament, which declared 2008 as the European Year of Intercultural Dialogue (for more details: European Parliament 2008). It ran from January to December 2008, and the aim was to show that this enormous diversity across Europe can be to our advantage if we can manage it at a high civilizing level. Throughout that year, various activities were organized to encourage every European to take advantage of the huge cultural heritage, as well as of the opportunities to learn and draw on different cultural traditions. The European Parliament has thus shown considerable interest in strengthening intercultural communication aimed at improving relations between nations, ethnicities, religions and other cultural communities within the European Union. Intercultural dialogue is considered to be one of the main ways of preventing misunderstandings, conflicts, and disrespect in the area of freedom of religion and belief. In this context, Asma Jahangir ${ }^{10}$ expressed the belief that if intercultural dialogue is successful, it is possible that it will really strengthen tolerance, respect and understanding (Ibid).

On the basis of intercultural communication, it is possible to seek and find that what connects people or, on the contrary, to emphasize the differences between them. ${ }^{11}$ In this process of mutual

\footnotetext{
10 United Nations Special Rapporteur on Freedom of Religion and Belief.
} 
value activity, there is an interaction of values and value orientations of communication participants, while as mentioned above, the important prerequisite for successful intercultural communication of communication participants is the agreement on some common values, but also intercultural competencies $^{12}$ of participants, representatives of individual cultures, etc. Through intercultural communication, problems should be solved that relate not only to the coexistence of cultures and their members in society, but also in general - to the life in the globalized world. In this world, we encounter several types of global problems that affect practically all people on Earth. They appear in specific forms (State, regional, etc.) and are also referred to as global. They are accompanied by global and transnational threats, such as climate change or pandemic.

Průcha concisely characterizes intercultural communication as a reflection of a real existing phenomenon, which occurs daily and which significance is constantly growing due to the growing globalization tendencies in many spheres of human activity (Průcha 2010). An example of this is also the COVID pandemic, which in today's globalized society, affects people without distinction and regardless of their cultural affiliation or the territory in which they live.

\section{Research methodology}

The paper comes from the theoretical research and qualitative analysis of sources that are information sources from the fields of some social sciences and humanities (social philosophy, sociology, social pedagogy, etc. It is based on the definition of multiculturalism, and on the work of some representatives of the socio-philosophical direction - communitarianism. The attention is firstly paid to the policy of multiculturalism that is used for supporting socializing of various groups of people in multicultural society. It requires the openness of one culture towards another one and helps leading constructive dialogues of cohabitation and other challenges. Its establishment and implementation clearly presupposes, among other things, also intercultural communication.

In the next part of the paper, intercultural communication defined through theoretical sources, primarily as a type of social interaction, while at first the phenomenon of communication is explained through sociology and linguistics, and then intercultural communication.

We posit that the study of intercultural communication should be based on three related concepts: communication, culture, and interculturality, with the main focus on the social aspect of intercultural communication. Our main goal is to point out its importance in the socialization of members of the multicultural society, as well as in achieving cooperation in solving problems, including global problems. The main attention is focused on the importance of intercultural communication in solving a current global problem - the COVID pandemic. It is one of the ways of how to develop and support successful global cooperation on solving coronavirus pandemic and it needs to rely on common values.

Regarding the fact that the pandemic is afflicting people around the world, it is a problem that requires the cooperation of experts from various scientific disciplines and various parts of the world. The article points out the important place of intercultural communication in political discussions and in the discussions of some experts in international forums and in scientific communities. It is noted that the COVID pandemic is also a current problem for global bioethics, and its solution requires the implementation of intercultural dialogues between experts from this field, while on behalf of the

\footnotetext{
11 In this respect, intercultural communication is about the combination of ethical universalism and particularism. Particularism is based on the experience of connection, through which we realize that we are connected with lives of others (Jurová 2013: 175). At the same time, it can be agreed that it is a universalist requirement, as it requires the recognition of all groups (Ibid). On the other side, particularism highlights relationships and stable ties to the community that help its members in moral and mental development. These are the benefits that shall be recognized and protected, even at the expense of universalist ideas.

12 Intercultural competence according to the Common European Framework of Reference (CEFR) can be understood as: 1) the ability to interconnect the initial and target culture; 2 ) the sensitivity toward culture and the ability to identify and use various strategies needed to interact with members of other cultures; 3 ) the ability needed to fulfil the role of cultural mediator between own and foreign culture, and the ability to deal effectively with misunderstandings and conflicts of intercultural character; 4) the ability to overcome stereotyped relations (Council of Europe 2017).
} 
common good - which is gaining the collective immunity - there is a call for the shift from particularism and for the adoption of the universally valid norm aimed at the benefit of everyone.

\section{Results and discussion}

Solving the current global problem: The COVID-19 pandemic through intercultural communication

There is no doubt about the negative effects of the globally spreading COVID-19 pandemic on human life in all parts of the world, and no doubt about the changes in global social dynamics. It is important to realize that this is global problem that requires global solutions. We agree with the opinion of prof. J. Bryson, that "The future of humanity requires the development of a new form of effective global governance that will develop and implement effective solutions of global problems" (Bryson 2021). Currently, according to him, the problem is that our management structures are based on the protection of a defined territory and people instead of the protection of humanity (Ibid.). It cannot be denied that States, politicians and other subjects around the world are starting to realize the need for cooperation in order to ensure a safer world for life. For example, the EU and its Member States are cooperating on strengthening national healthcare systems and are currently working to prevent the spreading of COVID-19. At the same time, they are adopting measures to mitigate the socio-economic impact of the disease and to support recovery. In this regard, the European Commission has presented a proposal for a transatlantic agenda, which includes areas: common work for a healthier world - while the priority is the mentioned pandemic; working together to protect the planet and prosperity; working together on technologies, trade and standards; and working together on a safer, more prosperous and more democratic world. At the same time, the EU wants the U.S. government to support global cooperation against the coronavirus pandemic, too. More specifically, this means cooperating in the global distribution of vaccines, tests and treatments, facilitating trade with basic sanitary goods, as well as reforming the World Health Organization (Euractiv 2020). The proposal concerns mainly political cooperation, which will involve people from various cultures. As in solving of other global challenges, as well as in solving the coronavirus pandemic, it is expected from people to work together in the world, regardless their cultural background. The question arises: What common values should cooperation of people as representatives of various cultures be based on? That is the question for politicians, politologists, sociologists but also economists and ethicians.

We consider intercultural communication based on common values to be one of the ways to develop and support successful global cooperation in addressing the coronavirus pandemic. The common values should guide the behaviour of individuals and groups as members of the global world, while with common shared values the ethical norms are creating on which the global ethics is based. ${ }^{13}$ Intercultural communication arises from the awareness of global belonging and coresponsibility, and encourages solidarity as well as commitment in the common good. Although the multicultural community is not based on a single philosophy, a single religion, a single moral, and therefore common values, this does not mean that its members shall not recognize some of the same values, moral norms, and common ideals. As $\mathrm{H}$. Küng points out, today there is a general agreement that: "Without a minimum basic consensus on certain values, norms, and attitudes, human dignified coexistence cannot be possible in a small or large community" (Küng 1992: 3). Finally, the policy of equal dignity is based on this view too.

The former French president Giscard d'Estaing emphasized that: "Solidarity is the cornerstone of our Union and it must play even bigger role in the times of crisis in order to reaffirm its strength and the fact that these are not just empty words. As Europeans, we must understand that this is not a zero-sum game - we are winning or losing together" (Giscard d'Estaing 2020). At the same time, he calls for the defence of universal values in the world that is committed to the temptation of power struggles, and he emphasizes that: "Our European Union is a union of values based on human

\footnotetext{
${ }^{13}$ Global ethics examines ethical issues and problems arising from global interconnection. On the basis of this ethics, the standards are being defined that should guide the behaviour of individuals and collective entities as members and participants on the global basis (Hutchings 2010).
} 
dignity, freedom, democracy, legally consistent state and peace" (Ibid). These values are the basis for the political integration of its members, as well as for the solution of common problems, and thus also for the current global problem - the COVID pandemic. However, this presupposes further discussions not only in the field of politics, but also in the field of medicine, epidemiology and also in the field of bioethics as well as other areas and scientific disciplines.

Solution for pandemic should rely on a mutual agreement that adjusts recognized values in current political talks among states but also cultures that result in such decisions as for example agreement of EU leaders on donation at least 100 million doses of vaccines in the countries in need. There is no mention on which cultures citizens identify with (Rada Európskej únie 2021a).

Similarly, the pandemic is perceived as a common problem, global problem that touches every person in a globalized world regardless of which culture they are.

The G7 Summit in June this year under the umbrella topic of "recovery for the better" after the pandemic the communiqué "Our shared agenda for global action to build back better" was agreed. The summit leaders regardless of cultural or country origin discussed provision of vaccines via COVAX ${ }^{14}$, that is a pillar of vaccines in terms of ACT - Accelator, the instrument against COVID-19 to those who need it most. Apart from that they communicated the problems such as economic recovery, geopolitical challenges, business and development, support of open societies and democratic values, protection of environment (Rada Európskej únie 2021b).

Not all the countries have been involved in such talks and even if they do, it is not easy to consider all the results of such agreements in their home countries. As it is stated: "Despite pressure from religious groups, the government banned travel around these restricted areas to slow the spread of the disease. However, a group of religious people ignored the resolutions of the National Headquarters for Combating COVID-19 and spontaneously attended these shrines, and even licked the shrine, which is a very polluted place." (Jafari and Gharaghani 2020: 470). Use of religious leaders in limitations of spreads of epidemics and infectuous diseases seems to be a very useful strategy. The leaders are able to articulate the agreed policies in their communities. It is one of the most useful strategies in the countries with low education. Via these leaders and religious organizations it can be reached that for example the citizens in Iran can understand how dangerous are religious gatherings in the times of pandemic (Ibid). It also points at the significance of communication in the cultural scope that is initiated by the authority - a religious leader. Thus, rather than intercultural communication or political talks, the fight against the pandemic relies more on interpretation of the COVID problem to the leaders and the solutions to the agreed solutions from the summit. At the same time it can be assume that the restrictions regarding the pandemic will be in Iran determined by cultural specifics.

\section{Intercultural dialogues of bioethical experts on international forums}

Solution of COVID pandemics assumes other discussions, not only in the field of politics but also medicine, epidemiology, but also other scientific fields. The social function of science and all scientific fields lies in the fact that the most general aim that we are thriving for is good life, quality life, sustainable life and sustainable development, happiness, health and justice. Therefore it is natural that the ethics tries to reflect on different sides and views of life through various social spheres and fields (Klimková 2017: 12).

Current global bioethics also offers moral alternatives for the creation of normative criteria for solving this problem, as well as other problems. ${ }^{15}$ Until now, however, in the multicultural world, it has only taken a stand on issues such as the auctioning of human kidneys, the sale of human embryos via the Internet, female circumcision, or biopiracy, as a few examples. We are of the opinion that it is also necessary to look for the basis for global bioethics through intercultural communication. As in the creation of norms in politics, it should be based on universal human rights,

\footnotetext{
${ }^{14}$ COVAX is a global initiative focused on a fair approach towards COVID-19 vaccines under the supervision of the Global Alliance for Vaccines and Immunization, WHO and The Coalition for Epidemic Preparedness Innovation (CEPI).

${ }^{15}$ P. Sýkora drew attention to the acute need for global bioethics (see more in, for example, Sýkora 2007).
} 
but at the same time on global "bioethical rights", which reflect the contradiction between ethical universalism and particularism. ${ }^{16}$

It can be assumed that intercultural communication, with which we should reach a convention on the issue of solving the COVID pandemic, will bring certain solutions only in the countries of the West, respectively rich North, that look on the issue of human rights, including bioethical rights, conventionally. These countries more or less respect the key international bioethical documents ${ }^{17}$ which are not legally binding, but they have significant impact on the formation of bioethical standards in the world.

For global bioethics, the Covid pandemic is current problem the solution of which requires the implementation of several intercultural dialogues carried out by experts in international forums, but also in scientific communities, through the mass media and the like. Although global bioethics has so far focused mainly on the individual patient to protect his autonomy, today, in the context of the Covid pandemic, it should focus, for example, on advocating a new ethical tool - a collective immunity. Leading Slovak bioethicist P. Sýkora states in this context: "Collective immunity obtained by vaccination is the most effective, safest and fastest solution to return society to the normal order, from which everyone will benefit" (Sýkora 2021). In this respect, global bioethics should be based on the empirical results of biomedical research, on the basis of which it is possible to establish the common good for all people in the world, and thus the acquisition of collective immunity. It is an ethical universalism, a unified "law" or a universally valid norm that is for the benefit of everyone.

Through intercultural communication, it is possible to adopt some other compromises when dealing with the Covid pandemic and subsequently to set normative criteria. The aim of intercultural communication is to achieve the cooperation of States and cultures on the global level, and to find solutions which will not be really "natural" for every cultural or religious tradition, but which will be acceptable on the global scale. However, the question is how many people and from how many countries will engage in such talks within solving this pandemic. Of course, not only in the field of ethics and other humanities and social sciences, but especially in the field of medicine, natural sciences, and other fields of science and social life. We believe that, together with intercultural communication, terms such as discussion, discourse, scientific debate, political negotiation and the like, will be more often used in them. Given that this is a global problem, it will be beneficial to involve people from different cultures and from all parts of the world. The difference of the languages in which they will communicate with each other will probably not be the main problem.

The answer to the question of whether, in addition to vaccines which provide relatively effective protection against the pandemic, there is another, more effective solution to fight the pandemic and stop its spreading or to be effective in treatment, depends on many circumstances. Many people in modern societies seem to believe that the solution to this problem will come from experts of the rich North countries. As in this part of the world the advanced population lives, which is able to carry out demanding scientific research in the field of biomedicine, chemistry and other sciences with the help of modern technologies which, by the way, are quite expensive. When solutions come, we will be happy together. But providing that it will be a common solution, a "common medicine" for all. After all, the Covid pandemic is the common problem in our globalized world, and in accordance with the policy of equal dignity, all people should have the same right to such an invention. At the same time, however, there is a fear that the invention will be appropriated by its author, and thus it will become a valuable product or commodity for him, for which others will have to pay, if they want to live and survive. The question is whether these people, or these countries, will have sufficient means to

\footnotetext{
16 Universalism represents global morality. Its classic example is political and legal equality. It does not take into account origins or special relationships, but only objective and impersonal criteria. While particularism is an ethic of commitment, it is based on special and specific relationships, on blood relations and ties, religion, or on the local way of life (Selznick 2002). ${ }^{17}$ It is the Universal Declaration on the Human Genome and Human Rights (UNESCO 1997); Convention on the Protection of Human Rights and Dignity of the Human Being with regard to the Application of Biology and Medicine (Zbierka zákonov 2000); Universal Declaration on Bioethics and Human Rights (UNESCO 2005) and others, while all of them knot on the internationally established conception of universal human rights.
} 
ensure the sustainability of their own lives. They deserve basic human rights, but what if they fail to acquire the needed means to apply them.

\section{Conclusion}

The Covid pandemic has undoubtedly become one of the main topics in the multicultural world. Its solution requires adopting number of measures. The burden lies on the shoulders of politicians and especially experts. But respecting their recommendations concerns all of us. As the policy of equal dignity relying on respect and acknowledgment of every citizen are important in multicultural societies, the citizens of such societies are expected the same, respect, honour and acknowledgment of agreed solutions on international level that are accepted thanks to intercultural communication in politics or science.

So far, we rely only on some research results offered to us by the experts from several scientific fields, who continue to communicate about this problem and are trying to solve it. Politicians, local governments and other entities deal with this problem and discuss it intensively at the national and international level. In this case, we can mark intercultural communication particularly beneficial. It is an important conjunctive interaction between people from different cultures, it allows to gather and supplement knowledge, experience, opinions and beliefs, which can then be introduced to other people in individual countries. Not only in the developed countries of the world in which everybody is involved freely but also the societies in which the most citizens rely on their religion. Even if in these less developed countries there is knowledge, experience and accepted solutions on international levels mediated through their religious leader who is an authority for them, everyone has a possibility to engage in the communication in the abovementioned problem. The voluntariness and respect of decisions in developed and less developed countries are very important. People cannot be forced to agree or accept them unconditionally and implement them into their decisions and actions. They have "only" the moral obligation - to decide in favour of the common good, which is, on the basis of existing knowledge - the collective immunity. But for this, they will need only rational judgment and own conscience.

\section{References}

Bryson, J. (2021). Beyond Nation First? COVID-19, Climate Change and Global Solutions Required for Global Problems. https://www.birmingham.ac.uk/research/perspective/covid-climate-change-andglobal-solutions.aspx. Accessed on 10 May 2021.

Council of Europe. (2017). Spoločný európsky referenčný rámec pre jazyky. Bratislava: Štátny pedagogický ústav.

European Parliament. (2008). 5. Formal sitting - 2008, European Year of Intercultural Dialogue. https://www.europarl.europa.eu/sides/getDoc.do?pubRef=-//EP//TEXT+CRE+20080618+ITEM005+DOC+XML+VO//EN. Accessed on 19 May 2021.

Euractiv. (2020). Eurokomisia predstavila návrh transatlantickej agendy, na stole budú nové témy. https://euractiv.sk/section/vonkajsie-vztahy/news/eurokomisia-predstavila-navrh-transatlantickejagendy-na-stole-budu-nove-temy/. Accessed on 18 April 2021.

Giscard d'Estaing, V. (2020). Európska spolupráca v čase koronavírusu žije, nezastavila ju ani byrokracia. https://dennikn.sk/1865204/europska-spolupraca-v-case-koronavirusu-zije-nezastavilaju-ani-byrokracia/. Accessed on 16 May 2021.

Hall, E. T. (1959). The Silent Language. New York: Doubleday \& Company Inc.

Honneth, A. (1997). Sociální filosofie a postmoderní etika. Praha: Filosofia.

Hutchings, K. (2010). Global Ethics: An Introduction. Cambridge: Polity Press.

Jafari, H., \& Gharaghani, M. A. (2020). Cultural Challenges: The Most Important Challenge of COVID19 Control Policies in Iran. Prehosp Disaster Med., 35(4), 470-471.

Jakoubek, M. (2005). Multikulturalizmus vs. kultura. In T. Hirt, \& M. Jakoubek (Eds.), Soudobé spory o multikulturalizmus a politiku identit. (Antropologická perspektiva). Praha: Vydavatelství a nakladatelství Aleš Čeňek, 198-235.

Janoušek, J. (1984). Společná činnost a komunikace. Praha: Svoboda. 
Jurová, J. (2013). Pohl'ad do filozofie a etiky nového komunitarizmu. Boskovice: František Šalé ALBERT.

Klimková, A. (2017). O odbornej praxi v praxi. Košice: FF UPJŠ. s. 153

Krech, D., Crutchfield, S. \& Ballachey, L. (1968). Člověk v spoločnosti. Bratislava: SAV.

Kymlicka, W. (1995). Multicultural Citizenship. Oxford: Claredon Press.

Litters, U. (1995). Interkulturelle Kommunikation aus fremdsprachendidaktischer Perspektive.

Tübingen: Narr.

Lomnický, I., Lesková, A., \& Magová, L. (2019). Tvorivé a kritické myslenie v príprave učitelov etickej výchovy. Nitra: UKF.

Küng, H. (1992). Světový étos projekt. Zlín: ARCHA.

Marková, D., \& Mandzáková, S. L. (2014). Adlerova etika a psychológia v kontexte vzt́ahu so

Sigmundom Freudom. Społeczeństwo i Edukacja Society and Education, 15(3), 55-66.

Mill, J. S. (1995). O slobode. Bratislava: IRIS.

Mikulaštík, M. (2010). Komunikační dovednosti v praxi. Praha: GRADA.

Mikulášová, A. \& Mikuláš. R. (2014). Interkultúrna komunikácia. http://hyperlexikon.sav.sk/sk/pojem/zobrazit/autor/13/interkulturna-komunikacia. Accessed on 28 May 2021.

Moravčíková, E. (2020). HESLÁR KULTUROLOGICKÉHO POJMOSLOVIA. Interkultúrna komunikácia. CULTUROLOGICA SLOVACA, 2/2020, 94-95. http://www.culturologicaslovaca.ff.ukf.sk/images/No2_2020/Heslar_Interkult\%C3\%BArna\%20kom unik\%C3\%A1cia.pdf. Accessed on 19 May 2021.

Nakonečný, M. (2009). Sociální psychologie. Praha: Academia.

Průcha, J. (2010). Interkulturní komunikace. Praha: Grada Publishing.

Rada Európskej únie. (2021a). Pandémia ochorenia COVID-19 spôsobeného koronavírusom: reakcia EÚ. https://www.consilium.europa.eu/sk/policies/coronavirus/. Accessed on 24 June 2021.

Rada Európskej únie. (2021b). Summit skupiny G7, Cornwall, Spojené království, 11.-13. června 2021. https://www.consilium.europa.eu/cs/meetings/international-summit/2021/06/11-13/. Accessed on 24 June 2021.

Sartori, G. (2005). Pluralizmus, multikulturalizmus a přistěhovalci. Praha: Dokořán.

Selznick, P. (2002). The Communitarian Persuasion. Washing-ton, D. C.: Woodrow Wilson Center Press.

Slušná, Z. (2005). Metamorfózy kategórie „kultúra“. Kultúra a rôznorodost' kultúrneho. Acta Culturologica. Zväzok č. 13, 37-53.

Solík, M. (2010). Komunikácia v spoločenskom kontexte - uznanie ako intersubjektívny predpoklad. Communication Today, 41-57. https://www.communicationtoday.sk/download/2/2010/Solik\%20\%20СT\%202-2010.pdf. Accessed on 16 May 2021.

Sýkora, P. (2007). O potrebe globálnej bioetiky v multikultúrnom svete. Filozofia, 62(3), 191-202.

Sýkora, P. (2021). Môže byt' povinné očkovanie proti koronavírusu etické? https://www.ucm.sk/sk/aktuality/detail/2712/. Accessed on 09 May 2021.

Taylor, CH. (2001). Politika uznání. In Gutmannová, A (Ed.). Multikulturalizmus. Zkoumání politiky uznaní. Praha: Filozofický ústav AV ČR, 41-90.

UNESCO. (1997). Universal Declaration on the Human Genome and Human Rights. http://www.bioethics.sk/files/journal/1998-2.pdf. Accessed on 30 April 2021.

UNESCO. (2005). Universal Declaration on Bioethics and Human Rights. http://portal.unesco.org/en/ev.php-URL_ID=31058\&URL_DO=DO_TOPIC\&URL_SECTION=201.html. Accessed on 30 April 2021.

Vadíková, K. M. (2015). Etika transgeneračného zdielania zážitku v edukačnom procese. In M. Šauerová, Hošek (Ed.). Zážitková pedagogika - zdroj inspirace v edukační praxi (pp. 48-57). Praha: Vysoká škola tělesné výchovy a sportu PALESTRA, spol. s r.o.

Velek, J. (Ed.). (1996). Spor o liberalizmus a komunitarizmus. Praha: Filosofia.

Walzer, M. (2002). Hrubý a tenký o tolerancii. Bratislava: Kalligram. 
ERL Journal Volume 2021-1(5) - COVID-19 - A Source of Threats or Opportunities for Linguistic Education

Watzlawick, P., Bavelasová, J. B., \& Jackson, D. D. (1999). Pragmatika lidské komunikace. Hradec Králové: Konfrontace.

Zbierka zákonov. (2000). Dohovor o ochrane ludských práv a dôstojnosti človeka v súvislosti a aplikáciou biológie a medicíny. https://archiv.vlada.gov.sk/ludskeprava/data/files/4164.pdf. Accessed on 16 May 2021. 